\title{
ANALISIS RASIO KEUANGAN PERBANKAN SEBAGAI ALAT UKUR KINERJA KEUANGAN BANK (Studi Kasus PD. BPR Bank Daerah Lamongan Periode 2012 -2016)
}

\author{
Ruswaji \\ Universitas Islam Lamongan
}

\begin{abstract}
ABSTRAK
Penelitian ini bertujuan untuk mendeskripsikan kinerja keuangan bank berdasarkan hasil analisis rasio keuangan perbankan. Jenis penelitian yang digunakan dalam penelitian ini adalah jenis penelitian deskriptif dengan menggunakan pendekatan kuantitatif. Hasil analisis rasio keuangan perbankan pada analisis rasio rentabilitas, kondisi kinerja keuangan dapat dikatakan baik, rata-rata pada ROA sebesar 2,10\%, ROE sebesar 18,43\%, dan BO/PO sebesar 87,10\% telah memenuhi standar Bank Indonesia. Pada analisis rasio likuiditas menunjukkan kondisi kinerja keuangan PD. BPR Bank Daerah Lamongan 2012-2016 dapat dikatakan baik. Ratarata loan to deposit ratio (LDR) sebesar 85,61\% telah memenuhi standar yang ditetapkan Bank Indonesia. Pada hasil analisis rasio solvabilitas kondisi kinerja keuangan dapat dikatakan baik karena perolehan rata-rata pada capital adequacy ratio (CAR) sebesar 14,29\% telah memenuhi standar Bank Indonesia.
\end{abstract}

Kata kunci : rasio keuangan, kinerja keuangan

\section{PENDAHULUAN}

Dunia perbankan di Indonesia memasuki masa persaingan yang sangat kompetitif, hal ini disebabkan banyaknya bank yang beroperasi di Indonesia baik yang beroperasi secara lokal maupun yang beroperasi berskala internasional. Perkembangan dunia perbankan yang sangat pesat serta tingkat kompleksitas usaha perbankan yang tinggi dapat berpengaruh terhadap kinerja keuangan suatu bank. Lemahnya kondisi internal bank seperti manajemen yang kurang memadai, pemberian kredit kepada kelompok atau group usaha sendiri serta

modal yang tidak dapat mengcover terhadap risiko-risiko yang dihadapi oleh bank tersebut dapat menyebabkan kinerja bank menurun.Ukuran kinerja keuangan berdasarkan SK Men.Keu. Nomor KEP. 792/MK/IV/12/1970 tanggal 7 Desember 1970 tentang lembaga keuangan yang telah diubah dan ditambah terakhir dengan keputusan Menteri Keuangan No. 280/KMK/10/1989 tanggal 25 Maret 1989 tentang pengawasan dan pembinaan lembaga keuangan bukan bank serta ditindak lanjuti dengan Surat Edaran Bank Indonesia No. SE. 23/21/BPPP 
disebutkan bahwa kinerja lembaga keuangan adalah mengenai permodalan, kualitas aktiva produktif, aspek manajemen, rentabilitas, dan likuiditas.

Informasi mengenai laporan keuangan bank sebagai salah satu upaya untuk membantu para pelaku bisnis dalam menilai kondisi keuangan suatu bank. Laporan keuangan yang diterbitkan oleh bank merupakan salah satu sumber informasi mengenai posisi keuangan bank, kinerja serta perubahan posisi keuangan bank yang sangat berguna untuk menilai kinerja keuangan suatu bank. Laporan keuangan bank dapat dijadikan ukuran kinerja suatu bank dengan melakukan analisis laporan keuangan.

Analisis kinerja keuangan bank dimulai dengan me-review data laporan keuangan, menghitung, membandingkan atau mengukur, menginterpretasikan dan memberi solusi. Perhitungan yang dilakukan untuk menganalisis kinerja keuangan bank dapat dilakukan dengan menggunakan berbagai teknik analisis, diantaranya adalah dengan menggunakan teknik analisis rasio. Analisis rasio merupakan analisis yang digunakan untuk mengetahui hubungan pos-pos yang ada dalam suatu laporan keuangan atau pos-pos antara laporan keuangan neraca dan laporan laba rugi (Kasmir, 2012:72). Analisis rasio keuangan merupakan teknik analisis yang sering dipakai, karena merupakan teknik yang paling cepat untuk mengetahui kinerja keuangan bank.

Penelitian ini menggunakan pengukuran rasio keuangan perbankan yaitu rasio rentabilitas (earning ratios), rasio likuiditas (liquidity ratios), dan rasio solvabilitas (capital ratios). Alasan peneliti mengambil ketiga rasio keuangan tersebut adalah pertama mempermudah melihat perkembangan kondisi keuangan suatu bank secara periodik atau "time series". Alasan kedua karena rasio keuangan tersebut merupakan pengganti yang lebih sederhana dari informasi yang disajikan laporan keuangan suatu bank yang sangat rinci dan rumit. Ketiga dengan mengukur melalui rasio rentabilitas, likuiditas, dan solvabilitas, maka dapat dijadikan dasar penilaian kinerja keuangan bank. Kinerja keuangan bank merupakan kemampuan bank untuk memenuhi kewajiban jangka pendek dengan segera, mendayagunakan aktiva secara optimal, memenuhi kewajiban jangka pendek dan jangka panjang, serta menghasilkan laba. 
Perbedaan antara bank pemerintah dan bank swasta adalah terletak pada segi kepemilikannya. Bank pemerintah merupakan bank yang pendirian dan modalnya dimiliki oleh pemerintah, sedangkan bank swasta merupakan bank yang pendirian dan modalnya dimiliki swasta. Agar bank pemerintah dapat tumbuh dan berkembang di masa persaingan perbankan yang kompetitif, tentunya bank pemerintah harus mempunyai kinerja keuangan yang baik. Kinerja keuangan yang disajikan oleh bank dapat digunakan pihak-pihak yang terkait seperti investor, kreditor, dan pihak-pihak lain untuk memprediksi kinerja keuangan yang sebenarnya dan di masa yang akan datang pada setiap periode.

PD. BPR Bank Daerah Lamongan merupakan bank milik pemerintah kabupaten Lamongan yang seluruh sahamnya dimiliki oleh Pemerintah Kabupaten Lamongan sebesar 100,00\%. Peneliti memilih PD. BPR Bank Daerah Lamongan dikarenakan PD. BPR Bank Daerah Lamongan merupakan bank pemerintah yang mempunyai misi mendorong pertumbuhan ekonomi daerah dan perolehan laba yang optimal guna memberikan kontribusi PAD yang optimal. Hal ini dapat dibuktikan dengan perolehan laba PD. BPR Bank Daerah Lamongan yang mengalami peningkatan sebesar 2,073 milyar pada tahun 2012, 3,05 milyar pada tahun 2013, 4,09 milyar pada tahun 2014, dan 5,35 milyar pada tahun 2015 serta 7,01 milyar pada tahun 2016. Sedangkan kontribusi PAD juga mengalami peningkatan sebesar Rp 1,022 milyar pada tahun 2012, 1,140 milyar pada tahun 2013, 1,678 milyar pada tahun 2014, 2,252 milyar pada tahun 2015 dan 3,024 milyar pada tahun 2016. Survei yang dihasilkan Biro Riset Infobank untuk kelompok bank yang beraset $\mathrm{Rp} 250$ miliar sampai dengan kurang dari Rp 500 miliar pada tahun 2015, PD. BPR Bank Daerah Lamongan memperoleh peringkat sepuluh besar (infobanknews.2015).

Penelitian ini bertujuan untuk mendeskripsikan kinerja keuangan bank berdasarkan hasil analisis rasio keuangan perbankan.

\section{TINJAUAN PUSTAKA}

Setiap jenis usaha atau perusahaan mempunyai catatan laporan keuangan yang berguna untuk menguji dan mengetahui serta menilai kondisi dan posisi keuangan perusahaan tersebut. "Laporan keuangan adalah laporan yang menunjukkan kondisi keuangan 
perusahaan pada saat ini atau dalam suatu periode tertentu"(Kasmir, 2012:7).

Analisis laporan keuangan sangat bergantung pada informasi yang diambil dari laporan keuangan. Menurut Baridwan (2000: 17) "Laporan keuangan merupakan ringkasan dari suatu proses pencatatan. Merupakan ringkasan dari transaksi-transaksi keuangan yang etrjadi selama tahun buku yang bersangkutan."

Menurut Ikatan Akuntansi Indonesia (2002:2), mendefinisikan laporan keuangan sebagai berikut: Laporan keuangan merupakan bagian dari proses pelaporan keuangan. Laporan keuangan yang lengkap biasanya meliputi neraca, laporan rugi/laba, laporan perubahan posisi keuangan (yang dapat disajikan dalam berbagai cara seperti misalnya sebagai laporan arus kas atau laporan arus dana), catatan dan laporan lain serta materi penjelasan yang merupakan bagian dari laporan keuangan.

Kesimpulan dari berbagai definisi tersebut adalah bahwa laporan keuangan pada dasarnya merupakan suatu daftar yang di dalamnya berisi ringkasan atas transaksi yang terjadi selama tahun buku yang bersangkutan. Laporan keuangan pokok meliputi neraca, laporan rugi/laba, dan laporan perubahan posisi keuangan. Neraca menunjukkan jumlah aktiva, kewajiban, dan modal suatu perusahaan. Laporan rugi/laba menunjukkan hasil yang telah dicapai oleh perusahaan serta biaya-biaya yang dikeluarkan selama periode tertentu, sedangkan laporan perubahan posisi keuangan menunjukkan sumber dan penggunaan aatau alasanalasan yang menyebabkan perubahan modal perusahaan.

\subsection{Kinerja Keuangan Bank}

Kinerja keuangan adalah penentuan secara periodik tampilan keuangan berdasarkan sasaran, standar dan kinerja yang telah ditetapkan sebelumnya. Mengukur kinerja keuangan digunakan analisis keuangan karena analisis keuangan melibatkan penilaian terhadap keuangan dimasa yang akan datang, dan untuk menentukan keunggulan suatu kinerja. Kinerja keuangan bank dapat dinilai dari kinerja untuk tahun yang lalu maupun yang sedang berjalan dengan menganalisis laporan keuangan.

Penilaian kinerja keuangan dapat dinilai dengan perhitungan rasio keuangan. Rasio keuangan yang menghubungkan dua data keuangan (laporan keuangan), yaitu neraca dan laporan laba rugi. Nilai rasio keuangan tersebut yang nantinya dibandingkan dengan tolok ukur yang telah ada. 
Analisis dan interpretasi nilai rasio keuangan yang telah diperoleh dapat memberikan pandangan yang lebih baik dan mendalam tentang kinerja keuangan. Analisis kinerja keuangan bank mempunyai tujuan antara lain (Abdullah, 2005: 120):

1. Untuk mengetahui keberhasilan pengelolaan keuangan bank terutama kondisi likuiditas, kecukupan modal dan profitabilitas yang dicapai dalam tahun berjalan maupun tahun sebelumnya.

2. Untuk mengetahui kemampuan bank dalam mendayagunakan semua aktiva yang dimiliki dalam menghasilkan profit.

Adanya informasi yang benar dan pemahaman mengenai kinerja bank maka diharapkan kepercayaan masyarakat terhadap perbankan semakin meningkat. Perhitungan yang dilakukan untuk menganalisis kinerja keuangan bank dapat dilakukan dengan menggunakan metode yang umum dilakukan, yaitu dengan menggunakan analisis rasio keuangan. Membandingkan nilai rasio keuangan yang diperoleh dari tahun ke tahun merupakan langkah berikutnya. Langkah ini perlu dilakukan guna mengetahui kondisi hasil perhitungan tersebut apakah baik atau kurang baik.

Perkembangan kinerja keuangan perusahaan akan dapat dilihat dari tahun ke tahun sehingga dengan melihat perkembangan tersebut perusahaan dapat membuat rencana-rencana untuk masa yang akan datang dan perkembangan yang tidak diinginkan haruslah segera diperbaiki dan diarahkan pada tujuan yang telah ditetapkan semula.

$\begin{array}{crr}\text { Langkah } & \text { selanjutnya } & \text { setelah } \\ \text { melakuan } & \text { perbandingan } & \text { adalah }\end{array}$
melakukan interpretasi terhadap hasil yang diperoleh. Interpretasi merupakan perpaduan antara hasil perbandingan dengan teori yang berlaku. Hasil interpretasi mencerminkan keberhasilan maupun permasalahan yang dicapai oleh perusahaan dalam pengelolaan keuangannya. Pemahaman atas masalah keuangan ang dihadapi oleh perusahaan akan dapat memberikan solusi yang tepat.

\subsection{Analisis Rasio Keuangan}

"Analisis perbandingan (ratio analysis) merupakan suatu teknik atau peralatan untuk mengevaluasi kondisi 
financial dan kinerja sebuah organisasi perusahaan." (Darmawi, 2011: 201).

Menurut Abdullah (2005: 123, "analisis ratio keuangan merupakan teknik analisis keuangan untuk mengetahui hubungan di antara pos-pos tertentu dalam neraca maupun laporan laba rugi baik secara individu maupun secara simultan."

Kesimpulan dari beberapa definisi bahwa analisis rasio keuangan merupakan suatu teknik analisis untuk mengevaluasi kondisi kinerja sebuah perusahaan dengan melakukan analisis pada laporan keuangan perusahaan tersebut.

Macam-macam rasio keuangan perbankan :

1. Rasio Rentabilitas

a) Return On Assets

b) Return On Equity (ROE)

c) Beban Oerasi / Pendapatan Operasi (BOPO)

2. Rasio Likuiditas

a) Cash Ratio (CR)

b) Loan to Deposit Ratio (LDR)

3. Rasio Solvabilitas

a) Capital Adequacy Ratio (CAR)

\subsection{Hubungan Laporan Keuangan sebagai Sumber Data dengan Penilaian Kinerja Keuangan}

Laporan keuangan merupakan suatu daftar yang di dalamnya berisi ringkasan atas transaksi yang terjadi selama tahun buku yang bersangkutan. Ringkasan dan transaksi yang terjadi selama tahun buku yang bersangkutan tersebut merupakan suatu sumber data yang dapat digunakan untuk mengukur kinerja keuangan bank. Mengukur kinerja keuangan bank dapat dilakukan dengan menggunakan analisis keuangan. Analisis laporan keuangan penting dilakukan untuk mengetahui kekuatan dan kelemahan suatu perusahaan. Informasi tersebut diperlukan untuk mengevaluasi kinerja yang dicapai manajemen bank di masa yang lalu serta sebagai bahan pertimbangan dalam menyusun rencana kinerja manajemen ke depan.

\section{METODOLOGI PENELITIAN}

Penelitian ini menggunakan jenis penelitian deskriptif dimana menurut Sugiyono (2005: 14) penelitian deskriptif adalah penelitian yang dilakukan untuk mengetahui nilai variabel mandiri, baik satu variabel atau lebih (independent) tanpa membuat perbandingan atau menghubungkan 
antara satu variabel dengan variabel lain. Menurut Kountur (2009:108), penelitian deskriptif adalah penelitian yang memberikan gambaran atau uraian atas suatu keadaan sejelas mungkin tanpa ada perlakuan terhadap objek yang diteliti. Tujuan dari penelitian deskriptif ini adalah untuk membuat deskripsi, gambaran atau lukisan secara sistematis, faktual, dan akurat mengenai fakta-fakta, sifat-sifat serta hubungan antar fenomena yang diselidiki.

Fokus penelitian dalam penelitian ini adalah: Analisis rasio keuangan bank yang sesuai dengan teori dan peraturan perbankan Indonesia yang relevan, yang terdiri dari: Rasio Rentabilitas ((Return On Assets, Return On Equity, dan Beban Operasi / Pendapatan Operasi (BOPO), Rasio Likuiditas (Cas Ratio $(C R)$, Loan to Deposit Ratio (LDR) dan Rasio Solvabilitas (Capital Adequacy Ratio (CAR).

Adapun tahapan-tahapan dalam analisis data dapat diperinci sebagai berikut:

1. Review data keuangan (laporan keuangan) bank khususnya yang berkaitan dengan kinerja keuangan pada PD. BPR Bank Daerah Lamongan. Laporan Keuangan tersebut terdiri dari Neraca, Laporan Laba Rugi, dan Perhitungan Tingkat Kesehatan Bank (CAMEL) tahun 2012-2016.

2. Melakukan perhitungan atas rasio rentabilitas, likuiditas dan solvabilitas pada Laporan Keuangan bank. Perhitungan ini menggunakan rasio keuangan perbankan yang terdiri dari:

a) Rasio Rentabilitas

1) Return On Assets (ROA)

2) Return On Equity (ROE)

3) Beban Operasi / Pendapatan Operasi (BOPO)

b) Rasio Likuiditas

1) Cas Ratio (CR)

2) Loan to Deposit Ratio (LDR)

c) Rasio Solvabilitas

1). Capital Adequacy Ratio (CAR)

Capital Adequacy Ratio (CAR)

bank yang bersangkutan.

\section{PEMBAHASAN}

\subsection{Rasio Rentabilitas}

Perkembangan ROA PD. BPR Bank Daerah Lamongan dalam lima tahun menunjukkan kecenderungan yang fluktuatif. Tahun 2012 nilai ROA 
sebesar $1,86 \%$ mempunyai arti bahwa manajemen bank mampu mendapatkan keuntungan sebesar $1,86 \%$ dari total aktivanya.

ROA PD. BPR Bank Daerah Lamongan mengalami peningkatan sebesar 0,03\% pada tahun 2013 menjadi 1,89\%. Pada tahun 2016, ROA PD. BPR Bank Daerah Lamongan mengalami penurunan sebesar $0,72 \%$ menjadi sebesar $1,84 \%$. Penurunan tersebut dikarenakan tidak berimbangnya peningkatan pada laba sebelum pajak menjadi Rp 9.346.779.000 dibanding peningkatan total aset pada tahun 2016 menjadi Rp 374.745.195.000. Penurunan signifikan tersebut menunjukkan bahwa kinerja manajemen bank dalam mengelola aktiva untuk mendapatkan laba tidak berjalan baik.

Perkembangan ROE PD. BPR Bank Daerah Lamongan dalam lima tahun menunjukkan kecenderungan yang fluktuatif. Perhitungan ROE PD. BPR Bank Daerah Lamongan pada tahun 2012 sebesar 12,80\%. ROE sebesar $12,80 \%$ ini mempunyai arti bahwa laba bersih yang dihasilkan oleh manajemen PD. BPR Bank Daerah Lamongan pada tahun 2012 sebesar $12,80 \%$ dari modal inti yang dimiliki, begitu pula pada arti ROE pada tahun-tahun berikutnya.
ROE PD. BPR Bank Daerah Lamongan mengalami peningkatan sebesar 3,21\% pada tahun 2013 menjadi $16,01 \%$. Peningkatan tersebut dikarenakan peningkatan pada laba sesudah pajak menjadi sebesar Rp 3.051.463.000 sebanding dengan peningkatan pada modal inti PD. BPR Bank Daerah Lamongan pada tahun 2013 menjadi Rp 19.056.684.000. Penurunan yang signifikan sebesar 2,91\% terjadi pada tahun 2016 menjadi sebesar 21,24\%. Penurunan tersebut dikarenakan tidak berimbangnya peningkatan pada laba sesudah pajak PD. BPR Bank Daerah Lamongan menjadi Rp 7.008.381.000 dibanding dengan modal inti yang dimiliki di tahun 2016 sebesar Rp 33.171.791.000.

Rasio BO/PO adalah perbandingan antara biaya operasional dan pendapatan operasional. Pendapatan operasional yang semakin kecil nilainya semakin bagus karena biaya operasionalnya dapat tertutupi dari pendapatan operasional. Perkembangan BO/PO PD. BPR Bank Daerah Lamongan mengalami penurunan yang signifikan sebesar 4,84\% pada tahun 2016 menjadi 79,66\%. Penurunan tersebut dikarenakan menurunnya rata-rata keseimbangan antara biaya operasional menjadi $\mathrm{Rp}$ 
48.667.111.000 dibandingkan rata-rata peningkatan pendapatan pada tahun 2016 menjadi sebesar Rp 57.604.206.000.

\subsection{Rasio Likuiditas}

Perkembangan Cash ratio PD. BPR Bank Daerah Lamongan dalam lima tahun menunjukkan kecenderungan yang fluktuatif. Tahun 2012 nilai cash ratio sebesar 7,56\% yang berarti bahwa bank mampu untuk membayar kembali simpanan sebesar $7,56 \%$ dari total simpanan yang dimiliki oleh para deposan maupun penabung, hanya dengan menggunakan cash assets yang dimiliki oleh bank pada tahun 2012. Begitu juga untuk tahun-tahun berikutnya.

Pada tahun 2013 cash ratio(CR) PD. BPR Bank Daerah Lamongan mengalami peningkatan yang signifikan sebesar $6,66 \%$ menjadi $14,22 \%$. Peningkatan tersebut disebabkan karena manajemen bank mampu meningkatkan cash assets pada tahun 2013 menjadi sebesar Rp 7.369.410.000 dibanding cash assets pada tahun 2012, sedangkan total simpanan (deposito dan tabungan) juga mengalami peningkatan menjadi sebesar Rp 173.693.577.000 dibandingkan pada tahun 2012.
Perkembangan loan to deposit ratio (LDR) PD. BPR Bank Daerah Lamongan dalam lima tahun menunjukkan kecenderungan menurun yang fluktuatif. Tahun 2012 nilai loan to deposit ratio sebesar $89,02 \%$, mengalami penurunan sebesar 0,98\% sehingga pada tahun 2013 nilai loan to deposit ratio menjadi $88,04 \%$. Pada tahun 2016 nilai loan to deposit ratio $\mathrm{PD}$. BPR Bank Daerah Lamongan mengalami penurunan menjadi sebesar 79,66\%. Penurunan tersebut dikarenakan tidak berimbangnya peningkatan antara kredit yaitu sebesar $\mathrm{Rp}$ 290.363.145.000 dengan peningkatan dana pihak ketiga menjadi Rp 364.512.891.000.

\subsection{Rasio Solvabilitas}

Capital Adequacy Ratio (CAR) adalah rasio yang memperlihatkan seberapa jauh seluruh aktiva bank yang mengandung risiko (kredit, penyertaan, surat berharga, tagihan pada bank lain) ikut dibiayai dari dana modal sendiri bank. Nilai CAR yang semakin besar maka semakin aman dana deposan pada bank yang bersangkutan. Perkembangan CAR PD. BPR Bank Daerah Lamongan dalam lima tahun menunjukkan kecenderungan yang fluktuatif. Tahun 2012 nilai CAR sebesar 13,90\%. 
Mengalami peningkatan pada tahun 2013 sebesar 1,44\% menjadi 15,34\%. Namun mengalami penurunan pada tahun 2014 menjadi 13,46\% hingga tahun 2015 menjadi sebesar 13,08\%. Penurunan ini disebabkan peningkatan pada modal bank yang tidak berimbang dibandingkan dengan peningkatan
ATMR. Pada tahun 2016 terjadi peningkatan yang signifikan sebesar $2,58 \%$ menjadi $15,66 \%$. Peningkatan ini terjadi dikarenakan peningkatan pada modal bank menjadi Rp 4.851.960.000.000 berimbang dengan peningkatan ATMR menjadi Rp 17.901.158.000.000.

Tabel 1. Rekapitulasi Perhitungan Rasio Keuangan PD. BPR Bank Daerah Lamongan

\begin{tabular}{|c|c|c|c|c|c|c|c|}
\hline \multirow{2}{*}{ Rasio } & \multicolumn{5}{|c|}{ Periode } & \multirow{2}{*}{ Rata-rata } & \multirow{2}{*}{$\begin{array}{c}\text { Ketentuan/ } \\
\text { Kriteria } \\
\text { Bank } \\
\text { Indonesia } \\
\end{array}$} \\
\hline & 2012 & 2013 & 2014 & 2015 & 2016 & & \\
\hline Rentabilitas & & & & & & & \\
\hline a. Return On Assets & $1,86 \%$ & $1,89 \%$ & $2,30 \%$ & $2,56 \%$ & $1,84 \%$ & $2,09 \%$ & $>1,215$ \\
\hline b. Return On Equity & $12,80 \%$ & $16,01 \%$ & $20,24 \%$ & $24,15 \%$ & $21,24 \%$ & $18,89 \%$ & $>17,5 \%$ \\
\hline c. Rasio $\mathrm{BO} / \mathrm{PO}$ & $89,00 \%$ & $89,06 \%$ & $87,12 \%$ & $85,82 \%$ & $84,49 \%$ & $87,10 \%$ & $<93,52$ \\
\hline $\begin{array}{l}\text { Likuiditas } \\
\text { a. Cash Ratio }(C R) \\
\text { b. Loan to Deposit }\end{array}$ & $7,56 \%$ & $14,22 \%$ & $15,67 \%$ & $19,61 \%$ & $22,43 \%$ & $15,90 \%$ & $>4,05$ \\
\hline Ratio (LDR) & $89,02 \%$ & $88,04 \%$ & $86,83 \%$ & $84,50 \%$ & $79,66 \%$ & $85,61 \%$ & $<94,75 \%$ \\
\hline $\begin{array}{l}\text { Solvabilitas } \\
\begin{array}{ll}\text { a. } & \text { Capital Adeuacy } \\
& \text { Ratio }(C A R)\end{array}\end{array}$ & $13,90 \%$ & $15,34 \%$ & $13,46 \%$ & $13,08 \%$ & $15,66 \%$ & $14,26 \%$ & $>8 \%$ \\
\hline
\end{tabular}

Sumber : data diolah.

Berdasarkan tabel rekapitulasi dengan tahun 2016 tersebut cenderung perhitungan rasio keuangan PD. BPR Bank Daerah Lamongan dapat dilihat bahwa pada rasio rentabilitas, kondisi kinerja keuangan PD. BPR Bank Daerah Lamongan tahun 2012-2016, dilihat dari return on assets (ROA) dapat dikatakan baik. Rata-rata return on assets sebesar $2,09 \%$ tersebut telah memenuhi kriteria standar yang ditetapkan Bank Indonesia sebesar $>1,22 \%$. Hasil perhitungan return on assets dari tahun 2012 sampai mengalami penurunan dikarenakan tidak berimbangnya perolehan laba yang dihasilkan dibanding dengan peningkatan total aset. Namun untuk perolehan keuntungan yang optimal mengalami peningkatan dari 2012 2016. Hasil penurunan pada perhitungan return on assets masih dapat dikatakan baik, karena nilai penurunan tersebut masih berada dalam standar Bank Indonesia. 
Pada hasil analisis return on equity, (ROE) kinerja keuangan PD. BPR Bank Daerah Lamongan dapat dikatakan baik. Rata-rata return on equity sebesar $18,89 \%$ tersebut telah memenuhi kriteria standar yang ditetapkan Bank Indonesia sebesar 17,5\%. Hasil perhitungan return on equity dari tahun 2012 sampai dengan tahun 2016 tersebut cenderung mengalami penurunan dikarenakan tidak berimbangnya peningkatan pada laba sesudah pajak PD. BPR Bank Daerah Lamongan dibanding dengan modal inti yang dimiliki di tahun 2016. Hasil penurunan pada perhitungan return on equity masih dapat dikatakan baik, karena nilai penurunan tersebut masih berada dalam standar Bank Indonesia.

Pada hasil analisis BO/PO, kinerja keuangan PD. BPR Bank Daerah Lamongan dapat dikatakan baik. Ratarata $\mathrm{BO} / \mathrm{PO}$ sebesar $87,10 \%$ tersebut telah memenuhi kriteria standar yang ditetapkan Bank Indonesia sebesar < 93,52\%. Hasil perhitungan BO/PO tahun 2012 sampai dengan tahun 2016 cenderung mengalami penurunan. Hasil penurunan pada perhitungan $\mathrm{BO} / \mathrm{PO}$ masih dapat dikatakan baik, karena nilai penurunan tersebut masih berada dalam standar Bank Indonesia.
Pada rasio likuiditas, kondisi kinerja keuangan PD.BPR Bank Daerah Lamongan pada tahun 2012-2016 dilihat dari cash ratio $(C R)$ dapat dikatakan baik. Perkembangan cash ratio PD. BPR Bank Daerah Lamongan yang berfluktuasi mengalami peningkatan yang signifikan di tahun 2013. Peningkatan tersebut disebabkan karena manajemen PD. BPR Bank Daerah Lamongan mampu meningkatkan cash assets pada tahun 2013 menjadi sebesar Rp 7.369.410.000 dibanding cash assets pada tahun sebelumnya. Nilai rata-rata cash ratio diperoleh sebesar 15,90\%; artinya setiap hutang lancar sebesar Rp 1 dijamin oleh aktiva lancar sebesar Rp 0,16 .

Pada rasio solvabilitas, kondisi kinerja keuangan PD. BPR Bank Daerah Lamongan pada tahun 2012-2016, dilihat dari capital adequacy ratio (CAR) dapat dikatakan baik. Rata-rata capital adequacy ratio sebesar $14,26 \%$ tersebut telah memenuhi kriteria standar yang ditetapkan Bank Indonesia sebesar $>8 \%$. Perkembangan capital adequacy ratio yang cenderung mengalami penurunan masih dapat dikatakan baik karena nilai capital adequacy ratio masih berada dalam standar Bank Indonesia. Pada hasil analisis debt to equity ratio, kinerja 
keuangan PD. BPR Bank Daerah Lamongan dapat dikatakan baik karena cenderung mengalami peningkatan. Dilihat secara keseluruhan peningkatan yang signifikan terjadi di tahun 2016. Peningkatan tersebut disebabkan karena terjadi peningkatan jumlah modal inti yang signifikan di tahun 2016 dibanding pada tahun sebelumnya.

\section{PENUTUP}

\subsection{Simpulan}

Hasil analisis rasio rentabilitas. Kondisi kinerja keuangan PD. BPR Bank Daerah Lamongan pada tahun 2012-2016 dilihat dari return on assets dapat dikatakan baik karena rata-rata return on assets sebesar 2,09\% telah memenuhi kriteria standar yang ditetapkan Bank Indonesia. Pada hasil return on equity kinerja keuangan dapat dikatakan baik karena rata-rata yang diperoleh sebesar $18,89 \%$ telah memenuhi criteria. Serta hasil BOPO kinerja keuangan dapat dikatakan baik karena rata-rata yang diperoleh sebesar $87,10 \%$ telah memenuhi criteria

Hasil analisis rasio likuiditas. Kondisi kinerja keuangan PD. BPR Bank Daerah Lamongan pada tahun 2012-2016 dilihat dari cash ratio dapat dikatakan baik karena dilihat secara keseluruhan hasil analisis cenderung mengalami peningkatan. Rata - rata loan to deposit ratio sebesar $85,61 \%$ telah memenuhi kriteria standar yang ditetapkan Bank Indonesia sebesar 78\% 100\%, mencerminkan kinerja keuanganyang baik.

Hasil analisis rasio solvabilitas. Kondisi kinerja keuangan PD. BPR Bank Daerah Lamongan pada tahun 2012-2016 dilihat dari capital adequacy ratio $(C A R)$ dapat dikatakan baik. Ratarata capital adequacy ratio sebesar $14,26 \%$ tersebut telah memenuhi kriteria standar yang ditetapkan Bank Indonesia sebesar $>8 \%$.

\subsection{Saran}

Diharapkan pihak manajemen PD. BPR Bank Daerah Lamongan melakukan upaya dalam menempatkan kelebihan dana pada bidang yang menguntungkan dan mempunyai tingkat keamanan.

Diharapkan pihak manajemen PD. BPR Bank Daerah Lamongan selalu berupaya untuk memaksimalkan atas penggunaan total aktiva dan modal yang disetor dalam upaya untuk meningkatkan pencapaian laba untuk rasio yang cenderung mengalami penurunan yaitu ROA dan ROE. 
Diharapkan pihak manajemen PD. BPR Bank Daerah Lamongan mempertahankan atas kemampuan yang dimiliki dalam upaya untuk menjaga kualitas permodalannya, dengan menjalin hubungan baik dengan para pemegang saham dan mempertahankan perolehan laba/rugi, serta menambahkan modal disetor untuk laba ditahan dari hasil keuntungan tahun sebelumnya agar diawal tahun berikutnya pihak bank akan mempunyai kelebihan modal untuk menjaga tingkat likuiditasnya.

\section{DAFTAR PUSTAKA}

Abdullah, Faizal .2005. Manajemen Perbankan (Teknik Analisis Kinerja Keuangan Bank).Malang: UMM Press.

Baridwan, Zaki. 2000. Intermediate Accounting. Yogyakarta: BPFE Universitas Gajah Mada.

Darmawi, Herman. 2011. Manajemen Perbankan. Jakarta: Bumi Aksara.

Dendawijaya, Lukman. 2005. Manajemen Perbankan.

Edisi Kedua. Jakarta: Ghalia Indonesia.
Ikatan Akuntansi Indonesia (IAI). 2002. Standar Akuntansi Kuangan (Revisi 2000). Jakarta: Slemba Empat.

Infobank. 2016. Rating 476 BPR terbaik 2016 Per Desember 2014 - 2016, Edisi Juli 2016.

Kasmir . 2010. Manajemen Perbankan. Jakarta: Rajawali Press.

\section{. 2012. Analisis}

Laporan Keuangan. Jakarta:

Rajawali Press.

Kountur, R. 2009. Metode Penelitian. Edisi Revisi. Jakarta: Buana Printing.

Sugiyono. 2008. Metode Penelitian Kuantitatif, Kualitatif dan $R \& D$. Bandung: Alfabeta.

Surat Edaran Bank Indonesia No. 13/ 30/ DPNP 16 Desember 2011, diakses pada Tanggal 16 Pebruari 2017 dari http://www.bi.go.id/.

Visi Misi PD. BPR Bank Daerah, diakses pada Tanggal Desember 2016. 
